\title{
Hellenic Natura 2000 Vegetation Database (HelNatVeg)
}

\author{
Panayotis Dimopoulos \& loannis Tsiripidis
}

\begin{abstract}
The Hellenic Natura 2000 Vegetation Database (GIVD ID EU-GR-005) was developed using TURBOVEG software package and currently comprises approximately 16,500 vegetation plots (relevés), most of which (ca. 14,000) were sampled during the years 1999 and 2000. The remaining relevés were derived from literature (period 1952 to 2000). Cover-abundance is given by the 7grade Braun-Blanquet scale for vascular plants. More than $90 \%$ of the plots are georeferenced and environmental data such as altitude, slope, aspect, geological substrate are given. All data refer to the Sites of Community Importance of the Natura 2000 network and all vegetation types of Greece that could be classified in the habitat types of the Dir. 92/43/EEC are represented. Vegetation and habitat maps of the sites are kept by the owner of the database. Quality control of relevés is necessary before use. The significance and usefulness of the HelNatVeg database is high as it includes about $40 \%$ of relevés ever sampled in Greece. Use of the database should be requested from the owner, the Hellenic Ministry of Environment, Energy and Climate Change.
\end{abstract}

Keywords: conservation; Greece; habitat type; plot; syntaxa; vegetation mapping.

\begin{tabular}{|c|c|}
\hline \multirow{2}{*}{\multicolumn{2}{|c|}{$\begin{array}{l}\text { GIVD Database ID: EU-GR-005 } \\
\text { Hellenic Natura } 2000 \text { Vegetation Database (HelNatVeg) }\end{array}$}} \\
\hline & \\
\hline \multicolumn{2}{|c|}{$\begin{array}{l}\text { Scope: Aiming at the identification, description and mapping of habitat types in sites of community importance for nature conservation in Greece, } \\
\text { almost } 14,000 \text { vegetation relevés have been carried out in 1999-2001, all stored in TURBOVEG. Plots taken from literature have also been } \\
\text { entered. The total number of relevés entered in HelNatVeg is } 16,439 \text {, assigned to all the vegetation syntaxa that correspond to habitat types of the } \\
\text { Directive } 92 / 43 / E \text { C. }\end{array}$} \\
\hline Status: completed and continuing & \\
\hline \multicolumn{2}{|c|}{ Database manager(s): Panayotis Dimopoulos (pdimopoul@uwg.gr); loannis Tsiripidis (tsiripid@bio.auth.gr) } \\
\hline \multicolumn{2}{|l|}{ Owner: Hellenic Ministry of Environment, Energy and Climate Change } \\
\hline \multicolumn{2}{|l|}{ Web address: $[N A]$} \\
\hline Availability: according to a specific agreement & Online search: no \\
\hline Database format(s): TURBOVEG & JRBOVEG, MS Access, Excel \\
\hline \multicolumn{2}{|l|}{ Publication: $[N A]$} \\
\hline Plot type(s): normal plots & $500 \mathrm{~m}^{2}$ \\
\hline Estimate of existing plots: $[\mathrm{NA}]$ & Completeness: [NA] \\
\hline Total plot observations: 13,862 & Valid taxa: 4,500 \\
\hline \multicolumn{2}{|l|}{ Countries: GR: $100.0 \%$} \\
\hline \multicolumn{2}{|l|}{ Forest: $[N A]$ - Non-forest: $[N A]$} \\
\hline \multicolumn{2}{|l|}{ Guilds: all vascular plants: $100 \%$} \\
\hline \multicolumn{2}{|l|}{ Environmental data: $[\mathrm{NA}]$} \\
\hline \multicolumn{2}{|l|}{ Performance measure(s): cover: $100 \%$} \\
\hline \multicolumn{2}{|c|}{ Geographic localisation: GPS coordinates (precision $25 \mathrm{~m}$ or less): $76 \%$; small grid (not coarser than $10 \mathrm{~km}$ ): $24 \%$} \\
\hline \multicolumn{2}{|c|}{ Sampling periods: 1950-1959: 0.3\%; 1960-1969: 11.6\%; 1970-1979: 1.7\%; 1980-1989: 1.7\%; 1990-1999: 41.7\%; 2000-2009: 41.6\% } \\
\hline Information as of 2012-07-12; further details and future updates available $\mathrm{ft}$ & m http://www.givd.info/ID/EU-GR-005 \\
\hline
\end{tabular}

Panayotis Dimopoulos* (pdimopoul@uwg.gr)

Department of Environmental and Natural Resources Management, University of Western Greece, Seferi 2, GR-30100 Agrinio, GREECE

Ioannis Tsiripidis (tsiripid@ bio.auth.gr)

School of Biology, Aristotle University of Thessaloniki, GR-54124 Thessaloniki, GREECE

*Corresponding author 